\title{
Metode High-Pass Filter Dan Fast Fourier Transform Untuk Perbaikan Citra Telapak Tangan
}

\author{
High-Pass Filter And Fast Fourier Transform Method For Improvement Of Palm Image \\ Mhd Furqan ${ }^{1}$, Sriani2, Muhammad Akbar Ramadhan Tanjung ${ }^{3}$ \\ Program Studi ilmu Komputer, Fakultas Sains dan Teknologi Universitas Islam Negeri Sumatera Utara \\ Jl. Lap. Golf No.120 Pancur Batu, Kabupaten Deli Serdang, Sumatera Utara \\ E-mail: mfurqan@uinsu.ac.id ${ }^{1}$, sriani@uinsu.ac.id ${ }^{2}$, \\ mhdakbarramadhan@uinsu.ac.id ${ }^{3}$
}

\begin{abstract}
Abstrak
Telapak tangan sering digunakan sebagai sumber penelitian dibidang sistem biometrik karena mempunyai karakteristik seperti sidik jari. Selain itu, telapak tangan juga mudah didapatkan dan dapat diperoleh dari citra yang memiliki resolusi rendah. Namun, selain itu juga sebuah citra telapak tangan akan dapat mengalami penurunan terhadap kualitasnya. Untuk itu dilakukanlah sebuah tahap yang dikenal dengan perbaikan kualitas citra, dimana bidang ini merupakan tahap awal dari pengolahan citra digital. Dalam penelitian ini penggunaan metode dalam perbaikan citra difokuskan untuk menajamkan citra telapak tangan dengan menggunakan high pass filter dan filter fast fourier transform, dimana sebelumnya citra tersebut telah diolah dengan menggunakan histogram ekualisasi untuk meningkatkan kontras citra telapak tangan. Setelah dilakukan pengujian terhadap 30 sampel citra. Dengan menilai error pada MSE (Mean Square Error) dan PSNR (Peak Signal to Noise Ratio) dari citra hasil rekonstruksi, hasil pengujian menunjukkan bahwa penggunaan high pass filter dengan koefisien=1 menghasilkan citra yang lebih baik dimana nilai rata-rata $\mathrm{MSE}=7,064544(\mathrm{~dB})$ dan $\mathrm{PSNR}=40,01314(\mathrm{~dB})$ daripada menggunakan high-pass filter dengan koefisien $=0$. Sedangkan pada fast fourier transform dengan menggunakan Ideal High-Pass Filter (IHPF) mampu menghasilkan citra rekonstruksi yang lebih baik dengan rerata $\mathrm{MSE}=9,354056(\mathrm{~dB})$ dan $\mathrm{PSNR}=38,537046(\mathrm{~dB})$ dari pada menggunakan butterworth high-pass filter (BHPF) dan gaussian high-pass filter (GHPF).

Kata Kunci: Citra, Perbaikan Citra, Sharpening, High Pass Filter, Fast Fourier Transform
\end{abstract}

\begin{abstract}
Palms are often used as research sources in the biometric system because they have characteristics such as fingerprints. Moreover, palms are also easy to acquire and can be obtained from an image that has a low resolution. Sometimes, however an image of the palm will be subject to drop in quality. For that goes a stage known as image enhancement, Where it's area the first stage of the digital image processing. In this study the use of methods in image enhancement was focused on sharpening a palm image using high pass filters and fast Fourier transform filters, where previously the image has been refined using a histogram equalization to enhance the contrast to the palm image. After testing 30 samples image. By judging an error on MSE and PSNR from reconstructive images, testing shows that coefficient use of a $H P F$ with $K=1$ produces a better image where the average value of $M S E=7.064544(d B)$ and $P S N R=40,01314(\mathrm{~dB})$ instead of using a high-pass filter with coefficients $K=0$. Whereas for on $F F T$ using the ideal high-pass filter (IHPF) it was able to generate better reconstruction images with equal value of MSE $=9.354056(\mathrm{~dB})$ and $P S N R=38.537046(\mathrm{~dB})$ than using a butterworth high-pass filter $(B H P F)$ and a gaussian high-pass filter (GHPF).

Keywords: Image, Image Enhancement, Sharpening, High Pass Filter, Fast Fourier Transform
\end{abstract}




\section{PENDAHULUAN}

Sebagai suatu fungsi menerus (continue) atas intensitas cahaya terhadap permukaan berdimensi dua ialah sebagai defenisi sebuah citra [1]. Citra (image) sebagai fungsi dua dimensi $f(x$, $y$ ) dimana $x, y$ representasi koordinat parsial dari tiap titik citra dan nilai fungsi $f$ pada kordinat $(x, y)$ sebagai nilai intensitas di titik itu [2].

Telapak tangan (palmprint) tak jarang dipakai sang para ilmuwan menjadi asal data penilitian khususnya dibidang sistem biometrik. Biometrika ialah ekspansi dari teknik fundamental untuk membedakan individu dengan memanfaatkan keunikan manusia biasa sebagai sumber data [3]. Telapak tangan mungkin merupakan bagian tubuh manusia yang paling dirinci pada bagian permukaan layaknya sidik jari. Tetapi tidak seperti sidik jari, walaupun bentuk telapak tangan sendiri dapat diverifikasi tetapi sebuah telapak tangan manusia tidak unique [4]. Kemudahan untuk diperoleh sehingga nyaman bagi pengguna merupakan keunggulan dari pemakaian telapak tangan. Detail pada telapak tangan tersebut mempunyai ciri yang lebih banyak dibandingkan sidik jari dan geometri tangan. Adapun ciri-ciri tersebut meliputi ciri geometri, garis-garis kusut, garis-garis prinsip/utama, serta ada ciri minusi dan titik delta [5].

Namun, apabila hasil dari citra telapak tangan yang didapat mengalami penurunan terhadap mutu/kualitasnya, hal tersebut mampu memberi dampak untuk karakteristik yang ada. Untuk mengatasi hal itu, maka di terapkanlah suatu tahap perbaikan kualitas citra. Tahapan-tahapan yang berusaha untuk merekonstruksi atau mengembalikan suatu citra yang terdegradasi sebagai defenisi dari perbaikan citra [6]. Perbaikan kualitas citra (image enhancement) ialah salah satu tahapan awal dalam pengolahan citra (image processing), dengan tujuan utama dari image enhancement adalah untuk mendapatkan detail lebih banyak dari suatu citra yang tersembunyi dari citra tersebut serta menyoroti informasi yang bermanfaat [7]

Begitu banyak teknik atau metode yang dipakai dalam proses perbaikan kualitas citra (image enhancement). Antara lain dapat menerapkan High Pass Filter (HPF) dan Fast Fourier Transform (FFT), dimana penggunaan kedua metode yang berbeda domain ini dapat diaplikasikan dalam mempertajam sebuah citra. Penapis lolos tinggi atau lebih dikenal dengan High-Pass Filter (HPF) merupakan dasar sebagian besar metode penajaman citra. Citra yang dipertajam saat kontrasnya ditingkatkan diantara area yang berdekatan dengan sedikit variasi dalam piksel yang cerah maupun gelap. Fast Fourier Tansform (FFT) merupakan sebagai salah satu metode dalam perbaikan kualitas citra yang berbasis transformasi. Dikenal sebagai salah satu metode transformasi yang populer dalam pengolahan citra digital.

Pada penelitian dengan judul "Palmprint Enhancement Using Discrete Curvelet Transform", dimana setelah mengevaluasi dari 100 tes yang dilakukan, hasil penelitian menunjukkan bahwa metode yang diusulkan yaitu Discrete Curvelet Transform (DCT) memberikan hasil yang lebih baik. Strategi ini dapat menghilangkan derau dalam gambar yang dikontraskan dengan metode adaptive histogram equalization (AHE), histogram equalization (HE) dan unsharp masking (UM) sehingga lebih banyak ciri yang dapat diekstrak dari telapak tangan [8].

Selain itu, ditahun 2011, penelitian berjudul "Teknik Pengolahan Citra Digital Berdomain Spasial Untuk Peningkatan Citra Sinar-X'. Dalam kesimpulan penelitiannya disebutkan bahwa proses image enhancement membuktikan dapat mengoptimalkan kualitas citra sinar-x yang mengalami penurunan kualitasnya saat digitalisasi citra. Beberapa teknik yang memiliki pengaruh yang besar seperti teknik histogram ekualisasi dan penajaman citra (image sharpening) [9].

Berdasarkan hasil review dari beberapa penelitian sebelumnya menunjukkan bahwa penerapan metode-metode image enhancement sendiri seperti Discrete Curvelet Transform, Histogram Ekualisasi dan Image Sharpening, cukup untuk mengoptimalkan citra yang terdegradasi. Tetapi dalam penelitian ini akan dilakukan kombinasi antara metode histogram ekualisasi dan metode penajaman citra (image sharpening) sehingga akan memberikan citra telapak tangan yang akan 
menampilkan lebih jelas lagi ciri-ciri yang ada pada citra telapak tangan, sehingga bisa meningkatkan keberhasilan dalam penelitian selanjutnya.

\section{METODE PENELITIAN}

Dalam perbaikan kualitas citra, ada 2 jenis pendekatan enhancement yang sering diterapkan yaitu metode dalam domain spasial dan metode dalam domain frekuensi [10]:

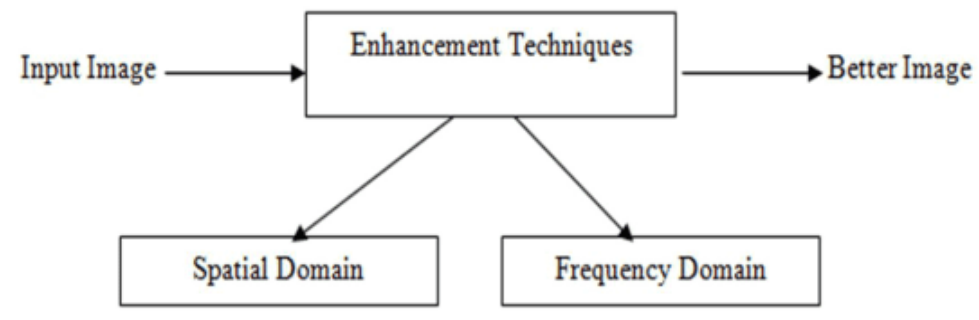

Gambar 1 Teknik Dalam Image Enhancement

Dalam teknik peningkatan citra domain spasial, transformasi diterapkan secara langsung pada piksel. Piksel nilai-nilai dimanipulasi untuk mencapai peningkatan yang diinginkan. Sedangkan, peningkatan citra dalam domain frekuensi yaitu dengan hanya menghitung transformasi Fourier gambar yang akan ditingkatkan, kalikan hasilnya dengan filter, bukan berbelit-belit dalam domain spasial, dan lakukan transformasi balikan (invers) untuk menghasilkan gambar yang telah ditingkatkan [11]. Model dasar untuk domain spasial dapat dilihat di persamaan (1) dan frekuensi pada persamaan (2).

$$
\begin{aligned}
& g(x, y)=T[f(x, y)] \\
& G(u, v)=H(u, v) * F(u, v)=
\end{aligned}
$$

High-Pass Filter (HPF) atau penapis lolos tinggi adalah salah satu dari metode penajaman (sharpening) dari domain spasial. Dimana tujuan utama dari proses penajaman adalah untuk menyoroti detail-detail halus dalam gambar atau untuk meningkatkan detail yang telah dikaburkan baik dalam kesalahan atau efek alami dari proses akuisisi citra tertentu. Metode Fast Fourier Transform (FFT )ini merupakan salah satu dari metode berdomain frekuensi. Perubahan Fourier mengisolasi sinyal menjadi berbagai frekuensi dalam kapasitas luar biasa yang kompleks [12].

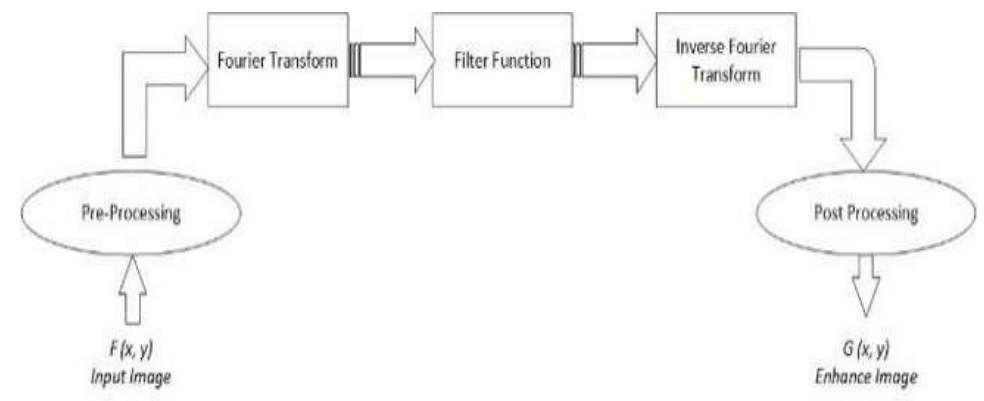

Gambar 2 Proses Filtering Pada Domain Frekuensi

Ditinjau dari gambar 2, proses pencitraan pada teknik peningkatan dalam domain frekuensi di ambil dari transformasi Fourier dari sebuah gambar, kalikan hasilnya dengan fungsi filter dan ambil Fourier terbalik (invers) untuk ditransformasikan agar mendapatkan gambar yang telah ditingkatkan [13]. Pada pengolahan citra digital, fast fourier transform bisa diterapkan dalam merpertajam citra 
(image sharpening), dimana pada domain frekuensi ada tiga filter yang digunakan, yaitu: Ideal HighPass Filter (IHPF), Butterworth High-Pass Filter (BHPF), Gaussian High-Pass Filter (GHPF). MSE dan PSNR dipakai untuk menguji kualitas citra hasil rekonstruksi, alasan penggunaannya MSE dan PSNR dalam mencari nilai error, hal ini menarik dikarenakan sederhana untuk menghitungnya, memiliki makna fisik yang jelas, dan praktis secara matematis dalam konteks optimalisasi [7].

\subsection{Dataset}

Teknik pengumpulan data di penelitian ini yaitu dengan teknik sampling, yakni dengan menggunakan purposive random sampling (pengambilan menurut tujuan). Sampel yang diambil pada pengumpulan data di penelitian ini dilakukan dengan cara mengumpulkan citra telapak tangan, yang di dapat penulis dari basis data telapak tangan (palmprint database) College of Engineering, Pune411005.

\subsection{Perancangan}

Tahap perancangan merupakan tahap setelah diterapkannya analisis kebutuhan. Dapat dilihat pada gambar 3 sebagai diagram perencanaan yang menjelaskan alur dari suatu sistem dalam melakukan proses enhancement pada sebuah citra telapak tangan. Yang dimulai dengan menginput citra, melakukan tahapan pre-processing, tahapan processing hingga sampai mencari nilai errornya.

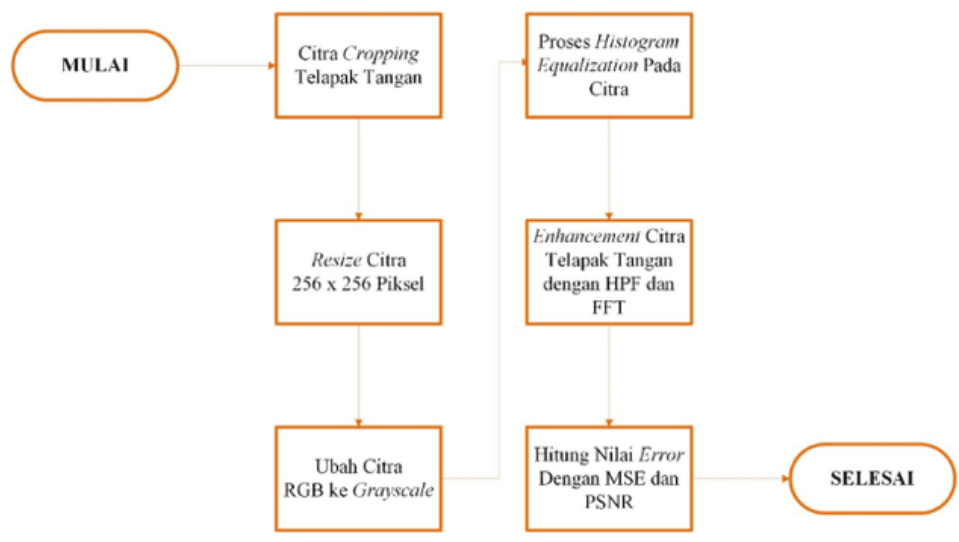

Gambar 3 Rancangan Diagram Perencanaan 

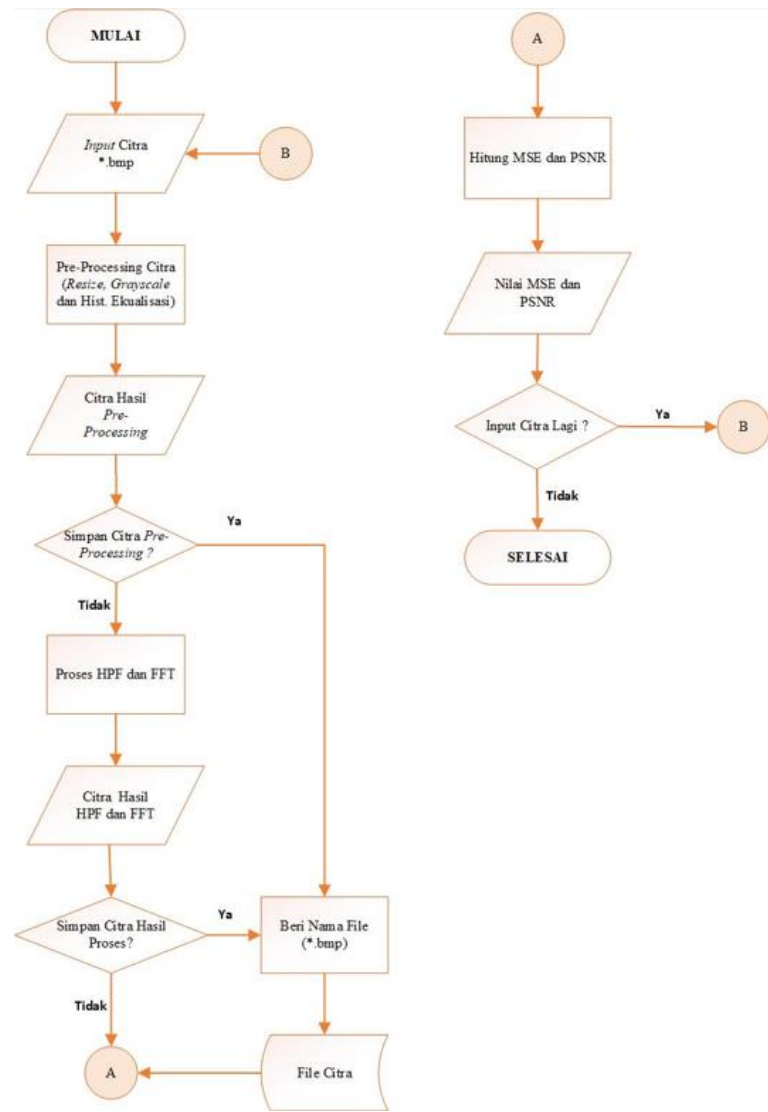

Gambar 4 Rancangan Flowchart Sistem Aplikasi

Gambar 4 adalah rancangan flowchart dari sistem aplikasi pada penelitian ini. Dimulai dari proses memasukkan citra awal, citra di pre-processing, citra di proses dan penghitungan nilai MSE dan PSNR dari citra akhir.

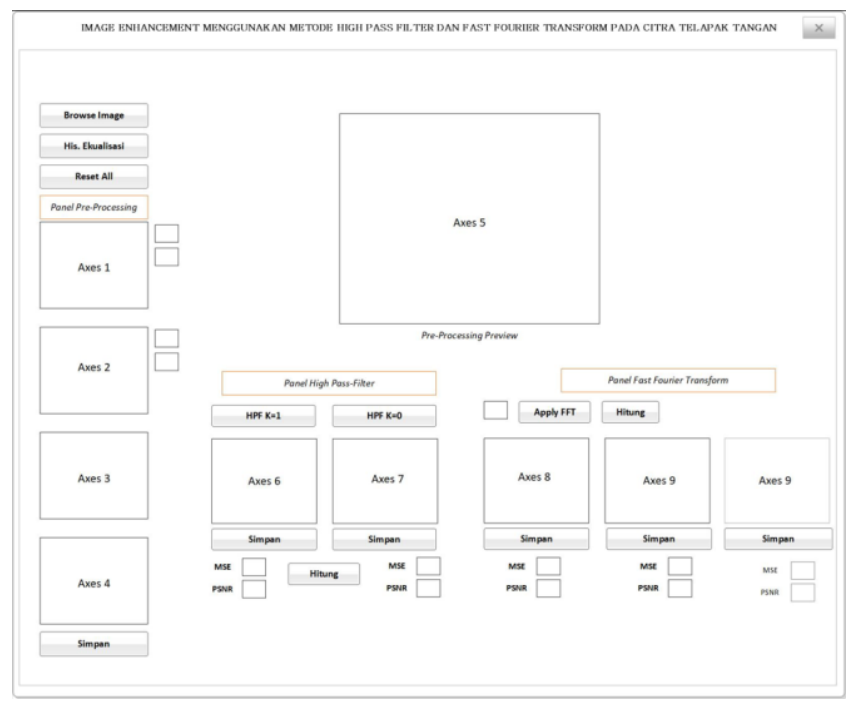

Gambar 5 Rancangan User Interface 


\section{HASIL DAN PEMBAHASAN}

\subsection{Analisis Data}

\section{Cropping dan Resize}

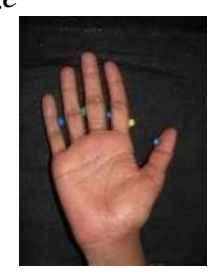

a

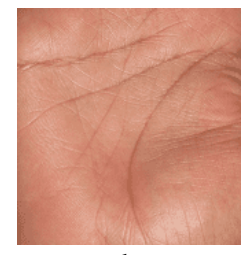

b

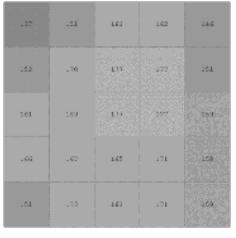

$\mathrm{C}$

Gambar 6 Representasi Citra Cropping dan Resize

Pada gambar 6(a), menunjukkan sebuah telapak tangan normal dengan kondisi utuh. Selanjutnya gambar 6(b), menampilkan sebuah citra telapak tangan yang telah di cropping yang hanya mengambil bagian yang diperlukan dalam penelitian ini serta telah di resize untuk mengubah ukuran menjadi 256 x 256 piksel. Gambar 6(c) adalah representasi citra telah diubah ke grayscale ukuran 5x5 yang digunakan sebagai sampel untuk perhitungan manual dalam penelitian ini.

\section{Grayscale}

Tahapan berikutnya adalah dengan mengubah citra berwarna (RGB) ke citra grayscale. Dari matriks citra RGB, dengan menggunakan persamaan (12), maka di dapatlah matriks grayscale.

$$
\begin{gathered}
\text { G. Scale }=0.299 * \mathrm{R}+0.587 * \mathrm{G}+0.114 * \mathrm{~B} \\
\qquad \begin{array}{cccc}
137 & 151 & 163 & 162 \\
152 & 170 & 177 & 177 \\
161 & 169 & 177 & 177 \\
166 & 167 & 165 & 171 \\
151 & 173 & 163 & 171 \\
\mathrm{a} & & \mathrm{b}
\end{array}
\end{gathered}
$$

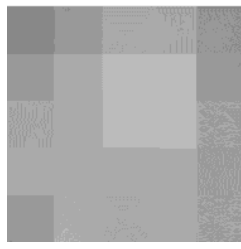

$\left[\begin{array}{ccccc}137 & 151 & 163 & 162 & 146 \\ 152 & 170 & 177 & 177 & 151 \\ 161 & 169 & 177 & 177 & 159 \\ 166 & 167 & 165 & 171 & 158 \\ 151 & 173 & 163 & 171 & 159\end{array}\right]$

Di gambar 7 merupakan bentuk dari matriks R,G, dan B. Dan pada gambar 7(a) menunjukkan hasil dari citra grayscale, sedangkan gambar 7(b) adalah representasi dari matriks grayscale.

\section{Histogram Ekualisasi}

Setelah citra grayscale didapat, selanjutnya yaitu dengan mengoptimalkan kontras citra memakai perataan histogram (histogram equalization). Dari matriks grayscale, dilakukanlah perhitungan untuk mendapatkan matriks histogram ekualisasi. 


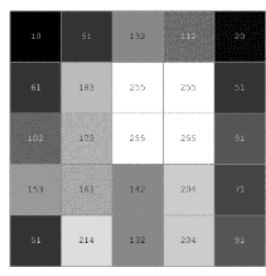

a

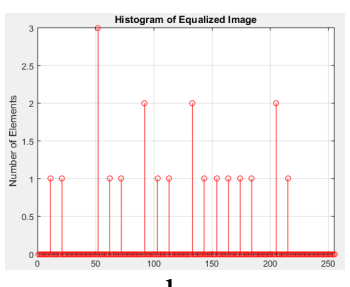

$\mathrm{b}$

Gambar 8 Representasi Histogram Ekualisasi

Gambar 8(a) adalah representasi piksel dari citra histogram ekualisasi, dan di gambar 8(b) sebagai histogram dari citra hasil penerapan histogram ekualisasi.

\section{High Pass Filter}

Selanjutnya, $f(x, y)$ didefenisikan sebagai matriks citra input dari hasil histogram ekualisasi dengan ukuran $5 \times 5$ dan $g(x, y)$ adalah sebagai kernel filter HPF dengan $\mathrm{K}=1$. Pada gambar 9 menunjukkan representasi piksel dari citra HPF.

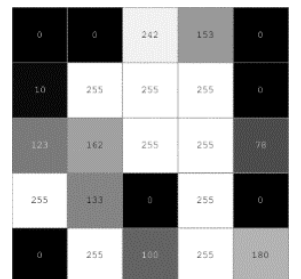

Gambar 9 Representasi Piksel HPF

\section{Fast Fourier Transform}

Ada beberapa langkah dalam memproses citra dengan menggunakan FFT, diantaranya adalah sebagai berikut:

- Transformasi Fourier Citra

Dengan mencari nilai matriks transformasi fourier dari citra input. Dimana citra yang digunakan adalah citra hasil histogram ekualisasi.

\begin{tabular}{|c|l|l|l|l|}
\hline 3341 & $\begin{array}{l}-854,958 \\
-370,477 i\end{array}$ & $\begin{array}{l}81,958 \\
-378,801 i\end{array}$ & $\begin{array}{l}81,958 \\
+378,801 i\end{array}$ & $\begin{array}{l}-854,958 \\
+370,477 i\end{array}$ \\
\hline$-514,109$ & $-125,640$ & 12,458 & $-183,955$ & 2,799 \\
$-191,522 i$ & $+249,042 i$ & $-37,053 i$ & $-164,590 i$ & $+246,456 i$ \\
\hline$-388,890$ & 70,955 & 90,140 & 139,200 & 79,541 \\
$+69,581 i$ & $+4,737 i$ & $+32,998 i$ & $-222,264 i$ & $-156,961 i$ \\
\hline$-388,890$ & 79,541 & 139,200 & 90,140 & 70,955 \\
$-69,581 i$ & $+156,961 i$ & $+222,264 i$ & $-32,998 i$ & $-4,737 i$ \\
\hline$-514,109$ & 2,799 & $-183,955$ & 12,458 & $-125,640$ \\
$+191,522 i$ & $-246,456 i$ & $+164,590 i$ & $+37,053 i$ & $-249,042 i$ \\
\hline
\end{tabular}

Gambar 10 Tabel Representasi Matriks Transformasi Fourier

- Filter Transformasi Fourier

Selanjutnya, dengan menentukan nilai jarak dari titik $(u, v)$ ke pusat frekuensi dengan menggunakan persamaan (4).

$$
D(u, v)=\sqrt{u^{2}+v^{2}}
$$


Setelah nilai jarak didapatkan, langkah berikutnya dengan mencari nilai kernel filter transformasi fourier yaitu IHPF, BHPF, dan GHPF dimana nilai $\mathrm{D}_{0}=20$ dan $n=2$. Kemudian, kalikan antara matriks hasil transformasi fourier citra dengan filter transformasi fourier.

\begin{tabular}{|c|l|l|l|l|}
\hline \multicolumn{1}{|c|}{0} & $\begin{array}{l}-1,068697 \\
-0,463096 i\end{array}$ & $\begin{array}{l}0,204649 \\
-0,945866 i\end{array}$ & $\begin{array}{l}0,306768 \\
+1,417852 i\end{array}$ & $\begin{array}{l}-4,26453 \\
+1,847939 i\end{array}$ \\
\hline$-0,642636$ & $-0,221252$ & 0,034683 & $-0,725334$ & 0,014378 \\
$-0,239402 i$ & $+0,438562 i$ & $-0,103155 i$ & $-0,648978 i$ & $+1,266044 i$ \\
\hline$-0,971058$ & 0,197538 & 0,317202 & 0,625008 & 0,443202 \\
$+0,173743 i$ & $+0,013187 i$ & $+0,116119 i$ & $-0,997965 i$ & $-0,874586 i$ \\
\hline$-1,455615$ & 0,313630 & 0,625008 & 0,476480 & 0,442120 \\
$-0,260441 i$ & $+0,618897 i$ & $+0,997965 i$ & $-0,174427 i$ & $-0,029516 i$ \\
\hline$-2,564375$ & 0,014378 & $-1,024997$ & 0,077625 & $-0,884254$ \\
$+0,955311 i$ & $-1,266044 i$ & $+0,917095 i$ & $+0,230877 i$ & $-1,752757 i$ \\
\hline
\end{tabular}

Gambar 11 Tabel Representasi Matriks Fourier Filter GHPF

Pada gambar 11 diatas, menunjukkan sebuah matrik transformasi fourier yang didapat dari matriks fourier citra yang dikalikan dengan kernel filter GHPF.

- Transformasi Fourier Balikan (Invers)

Mencari invers dari matriks transformasi fourier agar mendapatkan citra hasil rekonstruksi, dimana dapat dilihat pada gambar 12 .

\begin{tabular}{|c|c|c|c|c|}
\hline$(2,143705$ & $(-2,66756$ & $(0,663196$ & $(0,255713$ & $(-0,534180$ \\
\hline+0$)$ & $-1,155938 i)$ & $-3,065293 i)$ & $+1,181907 i)$ & $+0,231476 i)$ \\
\hline$(-1,604085-$ & $(-0,704742$ & $(0,131675-$ & $(-1,031847-$ & $(0,008736$ \\
\hline $0,597574 i)$ & $+1,396933 i)$ & $0,391611 i)$ & $0,923222 i)$ & $+0.768974 i)$ \\
\hline$(-3,14693$ & $(0,749915$ & $(1,397495$ & $(1,471171$ & $(0,643652$ \\
\hline$+0,563057 i)$ & $+0,050074 i)$ & $+0,511598 i)$ & $-2,349063 i)$ & $-1,270148 i)$ \\
\hline$(-1,213384$ & $(0,446162$ & $(1,471171$ & $(0,505615$ & $(0,221391$ \\
\hline$-0,217102 i)$ & $+0,880431 i)$ & $+2,349063 i)$ & $-0,185097 i)$ & $-0,014783 i)$ \\
\hline$(-0,321218$ & $(0,008736$ & $(-1,488585$ & $(0,038873$ & $(0,078500$ \\
\hline$+0,119664 i)$ & $-0,768974 i)$ & $+1,331880 i)$ & $+0,115611 i)$ & $-0,155603 i)$ \\
\hline
\end{tabular}

Gambar 12 Matriks Invers Fourier Transform Dengan Filter GHPF

\section{MSE dan PSNR}

Setelah didapat citra dari hasil HPF dan FFT, langkah selanjutnya adalah menghitung nilai MSE dan PSNR. Misalnya matriks yang akan dihitung adalah matriks dari histogram ekualisasi sebagai $f(x, y)$ dengan citra HPF sebagai matriks $g(x, y)$. Maka nilai MSE dan PSNR dari kedua citra adalah dimana MSE=3.31748 (dB) dan PSNR=42.92272 (dB). 


\subsection{Hasil Pengujian Sistem}

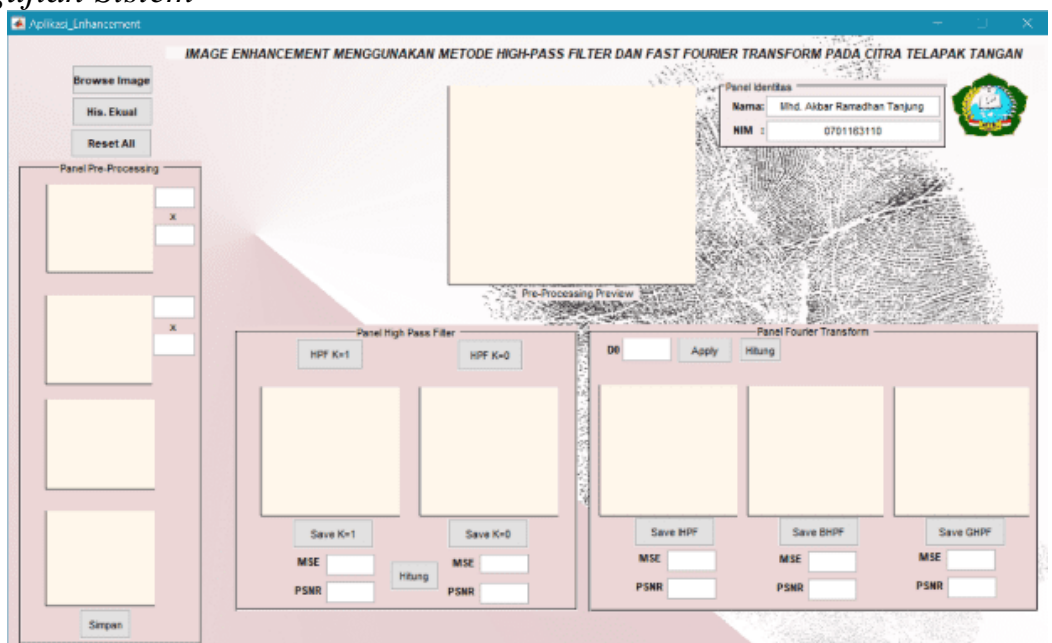

$\mathrm{a}$

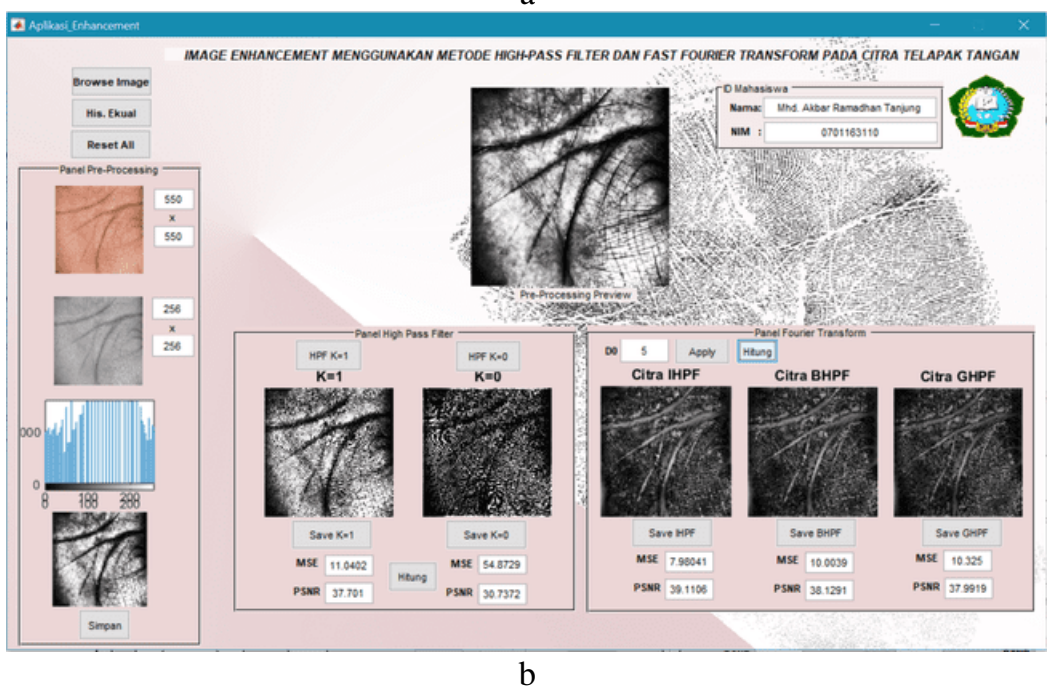

Gambar 13 Tampilan Pengujian Sistem

Pada gambar 13(a) ditampilkan user interface pada saat pertama kali menjalankan sistem aplikasi. Gambar 13(b) sebagai tampilan disaat citra mulai di input ke sistem sampai di proses serta perhitungan nilai MSE dan PSNR.

\subsection{Hasil Data Uji}

Berikut ini akan ditampilkan tabel rerata nilai error MSE dan PSNR dan grafik hasil pengujian dari 30 citra hasil rekonstruksi di dalam penelitian ini. Pada gambar 14(a) menunjukkan grafik dari hasil nilai MSE yang didapat dari 30 citra uji, dan di gambar 14(b) adalah tampilan grafik nilai PSNR dari citra uji. 
Tabel 1 Nilai Rerata Error

\begin{tabular}{|c|c|c|}
\hline & MSE & PSNR \\
\hline$H P F K=1$ & 7,064544 & 40,01314 \\
\hline$H P F K=0$ & 57,147663 & 30,56372 \\
\hline$I H P F$ & 9,354056 & 38,537046 \\
\hline$G H P F$ & 12,228967 & 37,33549 \\
\hline$B H P F$ & 11,978327 & 37,384943 \\
\hline
\end{tabular}

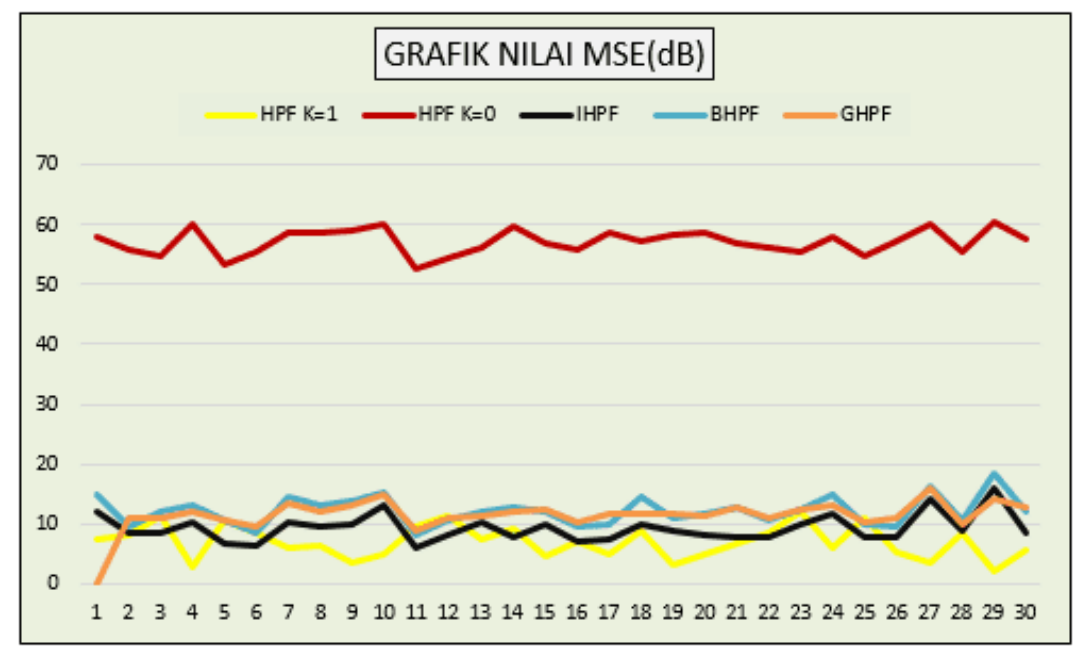

a

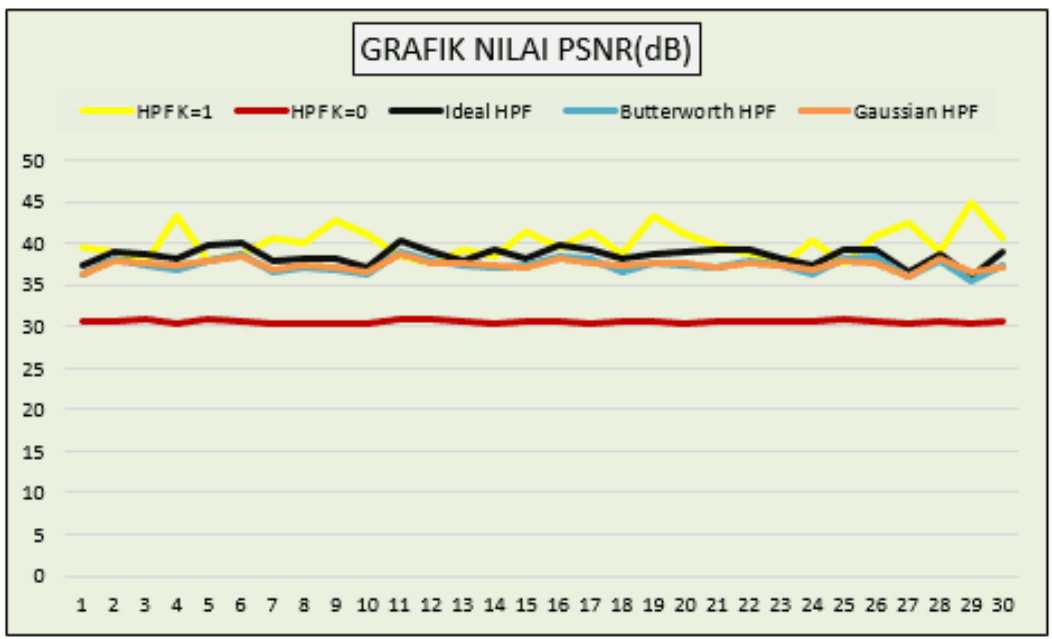

b

Gambar 14 Grafik Nilai MSE dan PSNR

Berdasarkan hasil pengujian yang dilakukan terhadap 30 sampel citra telapak tangan, menunjukkan hasil dimana HPF dengan $\mathrm{K}=1$ menghasilkan citra rekonstruksi yang lebih baik dengan rata-rata nilai $\mathrm{MSE}=7,064544(\mathrm{~dB})$ dan PSNR $=40,01314(\mathrm{~dB})$ dibanding dengan HPF dimana $\mathrm{K}=0$ menunjukkan nilai rata-rata $\mathrm{MSE}=57,147663(\mathrm{~dB})$ dan PSNR $=30,56372(\mathrm{~dB})$. Kemudian, penerapan metode Fast Fourier Transform terhadap citra telapak tangan, menunjukkan hasil dimana dengan menggunakan filter Ideal High Pass-Filter (IHPF) menghasilkan citra rekonstruksi yang lebih baik dengan rata-rata nilai MSE $=9,354056(\mathrm{~dB})$ dan PSNR $=38,537046(\mathrm{~dB})$ dibanding dengan filter Gaussian High Pass-Filter (GHPF) dimana menunjukkan nilai rata-rata MSE = 11,978327 (dB) 
dan PSNR = 37,384943 (dB) dan filter Butterworth High Pass-Filter (BHPF) order 2 dengan hasil rerata $\mathrm{MSE}=12,228967(\mathrm{~dB})$ serta nilai rerata PSNR $=37,33549(\mathrm{~dB})$.

Tabel 2 Citra Hasil Data Uji

\begin{tabular}{|c|c|c|c|c|c|c|c|}
\hline \multirow[t]{2}{*}{ No } & \multirow[t]{2}{*}{ Grayscale } & \multirow{2}{*}{$\begin{array}{l}\text { Histogram } \\
\text { Ekualisasi } \\
\end{array}$} & \multicolumn{2}{|c|}{ High-Pass Filter } & \multicolumn{3}{|c|}{ Fast Fourier Transform $\left(\mathrm{D}_{0}=5\right)$} \\
\hline & & & $H P F K=1$ & HPF $K=0$ & IHPF & $B H P F(n=2)$ & GHPF \\
\hline 1 & & & & & & & \\
\hline 2 & & & & & & & \\
\hline 3 & & & 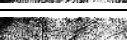 & $7=$ & & & \\
\hline 4 & & & 7 & & & & \\
\hline 5 & & & & & & & \\
\hline
\end{tabular}

Pada tabel(2), dapat dilihat ada beberapa citra telapak tangan hasil pengujian. Dimana dimulai dari citra yang telah dikonversi ke grayscale, kemudian citra histogram ekualisasi. Setelah itu, dilakukan tahap proses dimana dengan menggunakan metode HPF dengan $\mathrm{K}=1$ dan $\mathrm{K}=0$ yang berbasis domain spasial. Setelah itu, dari citra histogram ekualisasi dilakukan penajaman dengan metode berbasis domain frekuensi. Yang terdiri dari filter ideal high pass filter (IHPF), filter butterworth high pass filter (BHPF) dan gaussian high pass filter (GHPF). Dari citra tabel diatas, nilai deviasi $\left(\mathrm{D}_{0}\right)=5$ dan order $(n)=2$.

\section{KESIMPULAN DAN SARAN}

Berdasarkan beberapa rangkaian pengujian yang dilakukan terhadap sampel citra telapak tangan. Dimana nilai MSE dan PSNR dari pengujian, hal ini menunjukkan bahwa semakin rendah nilai MSE yang dibuat oleh gambar, semakin baik gambar yang dibuat ulang. Kemudian, jika nilai PSNR yang dihasilkan oleh gambar tersebut semakin besar, gambar yang dibuat ulang akan menunjukkan hasil yang bagus juga.

Selanjutnya, penerapan metode-metode dalam image enhancement seperti histogram ekualisasi, high-pass filter dan fast fourier transform mampu meningkatkan kualitas citra menjadi lebih baik, detail, dan jelas sehingga mudah diinterpretasikan manusia. Dimana dari kedua metode image sharpening tersebut, bahwa dari domain spasial menggunakan HPF dengan $\mathrm{K}=1$ lebih baik dari $\mathrm{K}=0$. Untuk yang berdomain frekuensi, dimana bahwa hasil filter IHPF lebih baik dari pada GHPF dan BHPF.

Penilitian ini hanya menggunakan citra telapak tangan dalam kondisi tangan normal. Diharapkan kedepannya akan ada kondisi baru dalam penggunaan citra telapak tangan seperti kondisi 
berminyak ataupun bernoda. Serta dengan menerapkan metode image enhancement yang lebih kompleks lagi, seperti metode peningkat kontras, penajaman citra, penghilang derau dan metode lain yang terkait sesuai kebutuhan citra dapat memberikan hasil yang lebih baik.

\section{UCAPAN TERIMA KASIH}

Terima kasih kepada Program Studi Ilmu Komputer Fakultas Sains Dan Teknologi Universitas Islam Negeri Sumatera Utara (UINSU) Medan, atas dukungan dalam terlaksanakannya penelitian ini.

\section{DAFTAR PUSTAKA}

[1] Sriani, Triase, and Khairuna, "Pendekomposisian Citra Digital Dengan Algoritma DWT," J. Ilmu Komput. dan Inform., vol. 01, no. 01, pp. 35-39, 2017.

[2] R. C. Gonzalez and R. E. Woods, Digital Image Processing Third Edition. 1992.

[3] R. A. Setiawan, R. R. Isnanto, and A. Hidayatno, "Identifikasi Diri Berdasarkan Biometrika Telapak Tangan Menggunakan Metode Tapis Gabor 2-D dan Jaringan Syaraf Tiruan Learning Vector Quantization (LVQ)," 2013.

[4] E. Prakasa and H. Herlan, "Pengujian Klasifikasi Pola Telapak Tangan dengan Menggunakan Rangkaian Matriks Sensor Cahaya," 2017.

[5] H. Dony, A. Putra, R. R. Isnanto, and A. A. Zahra, "Kinerja Pengenalan Sistem Biometrik Telapak Tangan Menggunakan Ekstraksi Ciri Berbasis Gelombang Singkat Biortogonal," vol. 4, 2015.

[6] M. Furqan, S. Sriani, and Y. K. Siregar, "Perbandingan Algoritma Contraharmonic Mean Filter dan Arithmetic Mean Filter untuk Mereduksi Exponential Noise," JISKA (Jurnal Inform. Sunan Kalijaga), vol. 5, no. 2, p. 107, 2020.

[7] A. G.Khandizod and R. R. Deshmukh, "Comparative Analysis of Image Enhancement Technique for Hyperspectral Palmprint Images," Int. J. Comput. Appl., vol. 121, no. 23, pp. 30-35, 2015.

[8] S. Palanikumar, M. Sasikumar, and J. Rajeesh, "Palmprint Enhancement Using Discrete Curvelet Transform," Int. J. Comput. Sci. Issues, vol. 8, no. 4, pp. 313-319, 2011.

[9] D. Priyawati, "Teknik Pengolahan Citra Digital Berdomain Spasial Untuk Peningkatan Citra Sinar-X," KomuniTi, vol. II, pp. 44-50, 2011.

[10] B. Rupa, G. Karuna, and G. V. R. Reddy, "A Survey on Spatial Domain Image Enhancement Techniques," IJRASET, vol. 6, no. IV, 2018.

[11] D. Titariya, R. Pandey, and S. Agrawal, "A Brief Review on Image Contrast Enhancement Techniques,” Int. J. Comput. Sci. Eng., vol. 7, no. 7, pp. 93-97, 2019.

[12] R. Y. Sipasulta, A. S. M. L. St, and S. R. U. A. Sompie, "Simulasi Sistem Pengacak Sinyal Dengan Metode FFT (Fast Fourier Transform)," E-Journal Tek. Elektro Dan Komput., vol. 3, no. 2, pp. 1-9, 2014.

[13] T. Rajasenbagam and S. Jeyanthi, "Image Enhancement Filtering Techniques to Enhancect Images of Lung Cancer,” Int. J. Innov. Technol. Explor. Eng., vol. 9, no. 4, pp. 241-248, 2020. 